\title{
INITIAL MATHEMATICS TEACHER TRAINING AT UNIVERSITY OF VIENNA
}

\author{
Petr Emanovský, Bronislava Štěpánková
}

\begin{abstract}
The quality of mathematics education is a very contemporary didactic topic at present. Improving the quality of this education is unthinkable without a quality mathematics teacher training at universities and other educational institutions. Many authors describe this issue (e.g. Hejný 2001, Monk 1994). The article deals with the contents and organization of the study programme for future teachers of mathematics at the Mathematical faculty of the University in Vienna of connection with the innovation of similar studies at the Faculty of Science of Palacký University, Olomouc that is realized within the ESF project "Professional science teacher training for careers in a competitive environment".
\end{abstract}

\section{Key words}

Teacher training, study programme, mathematics, University of Vienna.

One of the key activities of the ESF project entitled "Professional science teacher training for careers in a competitive environment" that is currently carried out at the Faculty of Science of Palacký University, Olomouc is innovation of the initial training for future teachers of scientific branches. A field trip to the Mathematical Faculty of the University of Vienna was organised within this core activity, among others. The aim of the trip was to familiarize ourselves with the content of studies for future teachers of mathematics at this university and consequently use the experience gained during the trip to deal with our project. The Austrian school system could bring us significant innovative ideas due to the common historical roots with our one (Greger, D. and Ježková, V., 2006).

In Austria, higher education belongs to the competence of the Federal Ministry for Science and Research. The largest and most important of these is the University of Vienna, which was founded in 1365 and is the oldest existing university in the German-speaking countries. 
Austria is a country with open access to higher education for all successful graduates of secondary schools and their interest is great. However, even for those who were not able to graduate from secondary school and whose age is between 25 and 45 years, access to tertiary education is not closed completely. According to the evaluation and job requirements one has the opportunity to study a particular study programme at a college. After successful completion of the so-called vocational graduation exam one can obtain permission for higher studies in the particular field.

Students at Austrian universities can study as ordinary, extraordinary or visiting students. The most common form of study is of course the ordinary one which is completed with the acquirement of a degree, i.e. diploma studies and doctoral studies. In addition, the short study can be expanded.

The diploma studies focus primarily on professional training necessary for future work of teachers. The length of the study is usually from eight to ten semesters and successful graduation is completed with the professional degree diploma. But not all students who start the study graduate successfully. Longterm monitoring shows that success of the study is just over fifty percent.

The time range of the short study is usually from four to six semesters and corresponds roughly to the first stage of the diploma studies. The end of the study is not associated with an academic degree, but with a professional designation.

The study of mathematics at the University of Vienna has a rich tradition and currently it is realized mainly on the Mathematical faculty. Bachelor studies of professional mathematics provide a comprehensive basic course in pure and applied mathematics. The bachelor's degree is followed by master's and doctoral degree programmes, some of which are taught in English. A set of related programs on the application of mathematics in economics is also provided by the Faculty of Economics.

The so-called parallel model of the structure of the study programme is predominant in the initial training of teachers of higher secondary schools in Austria, which means that academic and professional learning take place during the study time simultaneously (Nezvalová, 2002). Similar is the situation in the teacher's study of mathematics at the Mathematical Faculty of the University of Vienna, as shown in the tables. The study program "Teaching of Mathematics" consists of two parts with the standard length of study of four and five semesters (total length is roughly four and a half years). Math- 
ematics is combined with a second teaching subject, which is either science or computer science.

The standard length of the first stage of study is four semesters. Table 1 contains compulsory professional subjects of the first stage of studies, which are supplemented by one of the six compulsory optional didactically oriented subjects (Table 2). It is obvious that students do not have too much freedom in the choice of courses at the beginning of their studies. The study programme includes mainly compulsory subjects, among which "Introduction to the Study of Mathematics" has the key position. Within this course students should be familiar with basic mathematical concepts and methods. Pilot teaching of similarly oriented subject is currently realized at the Faculty of Science of Palacký University, Olomouc within our project. An equally important subject, which is included at the beginning of the study, is the subject of "Basic PC skills". The goal of the subject is to acquire basic skills and habits for working with a PC and then with a suitable mathematical software. These subjects are followed by two basic training courses in the first semes-

Tab. 1: The first stage of study: Mathematics - compulsory subjects

\begin{tabular}{|l|c|}
\hline \multicolumn{1}{|c|}{ Subject } & Number of hours \\
\hline Introduction to Mathematics & 3 \\
\hline Basic Work with PC & 2 \\
\hline Introduction to Analysis & 3 \\
\hline Exercise: Introduction to Analysis & 2 \\
\hline Analysis of One Variable for Teachers & 2 \\
\hline Exercise: Analysis of One Variable for Teachers & 2 \\
\hline $\begin{array}{l}\text { Real Analysis of Multiple Variables and Complex Analysis } \\
\text { of One Variable for Teachers }\end{array}$ & 5 \\
\hline $\begin{array}{l}\text { Exercise: Real Analysis of Multiple Variables and } \\
\text { Complex Analysis of One Variable for Teachers }\end{array}$ & 2 \\
\hline Introduction to Linear Algebra and Geometry & 3 \\
\hline Exercise: Introduction to Linear Algebra and Geometry & 2 \\
\hline Linear Algebra and Geometry for Teachers & 4 \\
\hline Exercise: Linear Algebra and Geometry for Teachers & 2 \\
\hline Theory of Numbers & 2 \\
\hline Exercise: Theory of Numbers & 1 \\
\hline Total & 35 \\
\hline
\end{tabular}


Tab. 2: The first stage of the study: Didactic of Mathematics - compulsory optional subjects

\begin{tabular}{|l|c|}
\hline \multicolumn{1}{|c|}{ Subject } & Number of hours \\
\hline School Mathematics 1 (Algebra and Arithmetic) & 2 \\
\hline Exercise: School Mathematics 1 (Algebra and Arithmetic) & 1 \\
\hline School Mathematics 2 (Geometry) & 2 \\
\hline Exercise: School Mathematics 2 (Geometry) & 1 \\
\hline School Mathematics 3 (Applied Mathematics) & 2 \\
\hline Exercise: School Mathematics 3 (Applied Mathematics) & 1 \\
\hline School Mathematics 4 (Vector Calculus) & 2 \\
\hline Exercise: School Mathematics 4 (Vector Calculus) & 1 \\
\hline School Mathematics 5 (Stochastics) & 2 \\
\hline Exercise: School Mathematics 5 (Stochastics) & 1 \\
\hline School Mathematics 6 (Differ. and Integ. Calculus) & 2 \\
\hline Exercise: School Mathematics 6 (Differ. and Integ. Calculus) & 1 \\
\hline Total & 3 \\
\hline
\end{tabular}

ter - "Introduction to Analysis" and "Introduction to Linear Algebra and Geometry", together with appropriate exercises. In the remaining semesters during the first stage of study, students complete other required courses (see Table 1). In addition, students attend one chosen subject which focuses on school mathematics, with the total time of 3 hours ( 2 hours lecture, 1 hour exercise).

The second stage of study normally takes five semesters. Students here attend other compulsory professional courses (Table 3 ) supplemented by three compulsory optional subjects (Table 4 and Table 5). The focus of the compulsory optional courses and seminars meets the requirements of current needs of teaching practice (e.g., "Gender Issues in Mathematics", "English for Mathematics", "Elementary Geometry", etc.). An important part of the second stage of the study is a set of compulsory didactically oriented subjects (Table 6). Basically, these are subjects that the students completed during the first stage, but this time they are designed with an emphasis on didactic aspects.

The teacher training would be unthinkable without practical experience, without teaching practice. The Mathematical Faculty of the University of Vienna provides its students with a special seminar of "Working in the school" focused on the preparation for independent teaching within the so-called first 
stage of the professional training, among others. However, the main focus of the practical training of teachers is represented by the second stage of the professional training (Unterrichtspraktikum), which involves one year of educational activities at school. However, this part of the training is not organized by the university, but by a relevant institute of further education.

Tab. 3: The second stage of study: Mathematics - compulsory subjects

\begin{tabular}{|l|c|}
\hline \multicolumn{1}{|c|}{ Subject } & Number of hours \\
\hline Applied Mathematics for Teachers & 3 \\
\hline Exercise: Applied Mathematics for Teachers & 1 \\
\hline Stochastics for Teachers & 4 \\
\hline Exercise: Stochastics for Teachers & 2 \\
\hline Differential Calculus for Teachers & 2 \\
\hline Exercise: Differential Calculus for Teachers & 1 \\
\hline Algebra for Teachers & 2 \\
\hline Exercise: Algebra for Teachers & 1 \\
\hline Practical Work with PC & 3 \\
\hline Total & 19 \\
\hline
\end{tabular}

Tab. 4: The second stage of study: Mathematics - compulsory optional subjects

\begin{tabular}{|l|c|}
\hline \multicolumn{1}{|c|}{ Subject } & Number of hours \\
\hline Gender Aspects in Mathematics & 2 \\
\hline The History of Mathematics and Logic & 2 \\
\hline Philosophy of Mathematics & 2 \\
\hline Elementary Geometry & 2 \\
\hline English for Mathematicians & 2 \\
\hline Total & 2 \\
\hline
\end{tabular}

Tab. 5: The second stage of the study: Mathematics - compulsory optional workshops

\begin{tabular}{|l|c|}
\hline \multicolumn{1}{|c|}{ Subject } & Number of hours \\
\hline Seminar for Teachers (Algebra) & 2 \\
\hline Seminar for Teachers (Applied Mathematics) & 2 \\
\hline Seminar for Teachers (Analysis) & 2 \\
\hline Seminar for Teachers (Stochastics) & 2 \\
\hline Total & 4 \\
\hline
\end{tabular}


Tab. 6: The second stage of the study: Didactic of Mathematics - compulsory subjects

\begin{tabular}{|l|c|}
\hline \multicolumn{1}{|c|}{ Subject } & Number of hours \\
\hline Introduction to Mathematics & 3 \\
\hline Basic Work with PC & 2 \\
\hline Introduction to Analysis & 3 \\
\hline Exercise: Introduction to Analysis & 2 \\
\hline Analysis of One Variable for Teachers & 2 \\
\hline Exercise: Analysis of One Variable for Teachers & 2 \\
\hline $\begin{array}{l}\text { Real Analysis of Multiple Variables and Complex Analysis } \\
\text { of One Variable for Teachers }\end{array}$ & 5 \\
\hline $\begin{array}{l}\text { Exercise: Real Analysis of Multiple Variables and } \\
\text { Complex Analysis of One Variable for Teachers }\end{array}$ & 2 \\
\hline Introduction to Linear Algebra and Geometry & 3 \\
\hline Exercise: Introduction to Linear Algebra and Geometry & 2 \\
\hline Linear Algebra and Geometry for Teachers & 4 \\
\hline Exercise: Linear Algebra and Geometry for Teachers & 2 \\
\hline Theory of Numbers & 2 \\
\hline Exercise: Theory of Numbers & 1 \\
\hline Total & 35 \\
\hline
\end{tabular}

Relationship between vocational and didactical training expressed by numbers of hours and in percentage is shown in the following two graphs. Note that as the didactical subjects are considered also all exercises of "subjects for teachers".

Fig. 1: Relationship between vocational and didactical training (number of hours)

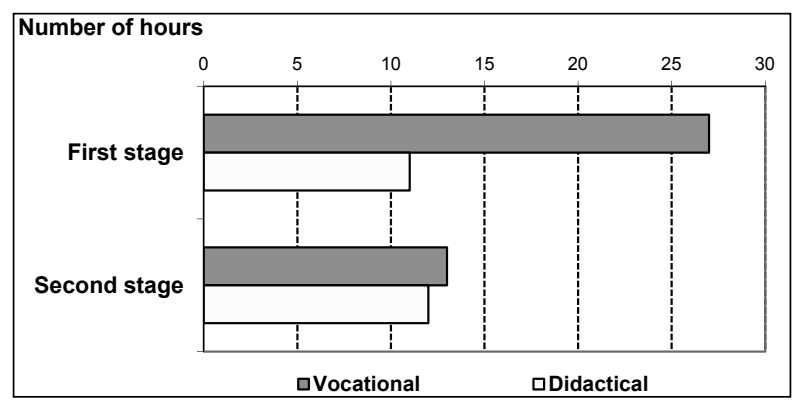


Fig. 2: Relationship between vocational and didactical training (percentage)

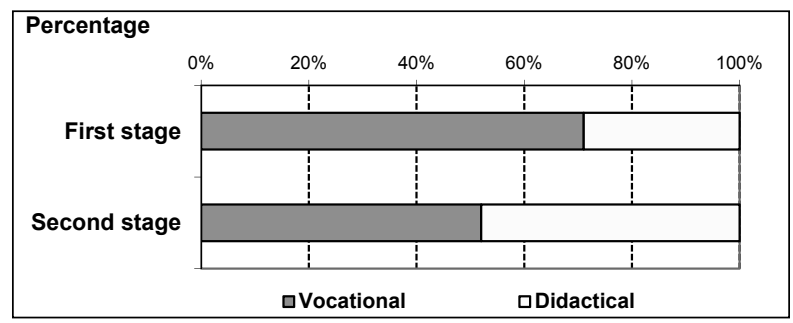

During our trip to the University of Vienna, we had an opportunity to visit teacher-training programme for teaching of mathematics, namely two subjects of the second stage of the study - "English for Mathematicians", conceived as CLIL - Content and Language Integrated Learning (see e.g. Novotná and Hofmannová, 2000) and "Practical work with PC". In both cases, we were pleasantly surprised, especially by the professional approach of the teacher and the naturally active and independent work of the students. In the course of "English for Mathematicians" we witnessed not only the very good language skills of the students but also group presentations with self-assessment, all of which required a minimal input on the teacher's part. The course "Practical Work with PC" was organized in the following way: it took place simultaneously in two classrooms led by students of higher classes supervised by one teacher. Within the subject, students were solving geometrical problems frontally using suitable software (GeoGebra - see e.g. Bímová, 2010). This subject has inspired us to create a new subject for our students - "Dynamic Models in Teaching of Stereometry".

All the suggestions and the valuable experience gained during our field trip to Vienna show the need of further improvement of teacher training for teachers of mathematics at the Faculty of Science of Palacký University, Olomouc. The training of future teachers should be realized in the spirit of strengthening their self-esteem, developing their ability to solve individual problems, leadership of professional discussions, searching, processing and presentation of information using the latest technology. Only teachers prepared in this way can succeed in today's highly competitive environment. 


\section{Acknowledgements}

This work was supported by the project CZ.1.07/2.2.00/15.0310 "Professional science teacher training for careers in a competitive environment".

\section{References}

ALLEMANN-GHIONDA, C. (2004). Einführung in die Vergleichende Erziehungswissenschaft. Weinheim und Basel: Beltz Verlag.

ALEXANDER, R. J. (2001). Border Crossings: towards a comparative pedagogy. Comparative Education, Vol. 37, Issue 4, pp. 507-523.

BÍMOVÁ, D. (2010). Using Geogebra in Teching Geometry and Mathematics. In: Proceedings of International Conference Presentation of Mathematics. Liberec: Technická univerzita, pp. 131-138.

GREGER, D., JEŽKOVÁ, V. (2006). Školní vzdělávání: zahraniční trendy a inspirace. Praha: Karolinum.

HEJNÝ, M. Problémy a zkušenosti s přípravou budoucích učitelů matematiky - úvaha (2001). In: Sborník materialu z celostátního semináré „Profesní competence učitele matematiky ve sjednocené Evropě". Chocerady: Univerzita Karlova v Praze, pp. 13-27.

MANOUCHERHRI, A. (1999). Computers and School Mathematics Reform: Implications for Mathematics Teacher Education. Journal of Computers in Mathematics and Science Teaching, 18(1), pp. 31-48. Charlottesville, VA: AACE.

MONK, D. H. (1994). Subject area preparation of secondary mathematics and science teachers and student achievement. Economic and Education Review. Vol. 13, Issue 2, pp. 125-145.

NEZVALOVÁ, D. (2002). Některé trendy v počáteční přípravě učitelů v zemích Evropské unie. e-Pedagogium, vol. 2, no. 2, pp. 34-45.

NOVOTNÁ, J., HOFMANNOVÁ, M. (2000). CLIL and Mathematics Education. In: Mathematics for Living. The Mathematics Education into the $21^{s t}$ Century Project. A. Rogerson (Ed.). Amman, Jordan, pp. 226-230.

PLANEL, C. (2008). The rise and fall of comparative education in teacher training; should it rise again as comparative pedagogy? Compare: A Journal of Comparative and International Education. Vol. 38, Issue 4, pp. 385-399. PRŮCHA, J. (2006). Srovnávací pedagogika. Praha: Portál.

VÁŇOVÁ, M. (2005). Úvod do srovnávací pedagogiky. Praha: VŠ J. A. Komenského. 
WALTEROVÁ, E. (2006). Srovnávací pedagogika. Praha: PedF UK.

\author{
Contact \\ Doc. RNDr. Petr Emanovský, Ph.D. \\ Department of Algebra and Geometry \\ Faculty of Science \\ Palacký University \\ Olomouc \\ Czech Republic \\ petr.emanovsky@upol.cz \\ PaedDr. Bronislava Štěpánková, Ph.D. \\ Institute of Education and Social Studies \\ Faculty of Education \\ Palacký University \\ Olomouc \\ Czech Republic \\ bronislava.stepankova@upol.cz
}

